\title{
To the Origins of American Archaeology in the Czech Lands: The Case of Julius Nestler
}

\author{
MARKÉTA KŘÍŽOVÁ
}

Center for Ibero-American Studies

Charles University, Prague, Czech Republic

krizova_ibero@seznam.cz

\begin{abstract}
The basis for the present article is the case study of Julius Nestler, amateur archaeologist from Prague, who at the beginning of the twentieth century pursued excavations in the ruins of Tiahuanaco and brought to Prague a unique collection of about 3,600 pieces, deposited now in the Náprstek Museum in Prague. His activities are put into the broader context of the origins of Americanist archaeology and anthropology in Central Europe, against a background of nationalist competition and economic entrepreneurship. The life story of Nestler also brings to the fore the problem of ethics in anthropological and archaeological work.
\end{abstract}

KEY WORDS: Julius Nestler, Nestler collection, Náprstek Museum, archaeology, anthropology, Tiahuanaco, history of archaeology and anthropology

Present-day Americanists often look back with appreciation, even with pride, to the first protagonists of the discipline, quoting from the works of the adventurous travelers and

The research for the present study was realized in the context of the program for development of science of Charles University in Prague PROGRES 9 "History: Key to understanding of globalized world".

DOI: 10.1515/eas-2017-0010 @ University of SS. Cyril and Methodius in Trnava. All rights reserved. 
studying the oldest museum collections or glass-negative photographs. But valuable as these testimonies might be, they need always to be evaluated and used with awareness of the social milieu in which they arose, as well as of the specific interests and motivations of those who produced them. Since their commencement in the nineteenth century, archaeology as well as anthropology had been under the influence of the reigning ideologies of the day, nationalism and imperialism, and this strongly shaped the nature of the research and the presentation of its outcomes; not to mention many other diverse factors, personal and social, that reflected on the scientific endeavors in specific regions and time-periods. In spite of the frequent pronouncements by the practitioners of these disciplines to avoid "all discussion of matters moral, political, and religious" ${ }^{\text {" }}$ and in this way free science from interest groups, state scrutiny, or political intervention, such pressures were inescapable.

\section{Political context of anthropology and archaeology}

The need to take into consideration the motivations and preconditions of anthropological and archaeological research before making use of its results will be demonstrated in the case study of one of the early protagonists of the study of America in the Czech Lands, Julius Nestler, who at the beginning of the twentieth century pursued research in Bolivia. Here he amassed an impressive collection of archaeological and ethnographical artifacts, deposited in the Náprstek Museum in Prague, and published several articles. As I already summarized Nestler's life and the story of the collection elsewhere, with all the bibliographical references to primary and secondary sources (KŘ́lZŽOVÁ 2016), in the present text I aim at analyzing in greater detail the specific case of Americanist studies in Central Europe in the pre-1918 period, against the background of the national competition and middle-class aspirations prevalent in the region. And, even more importantly, this case also brings to the fore the multifaceted problem of the ethics of anthropological and archaeological work.

The idea of there being a need to study the socio-political contexts of archaeological research was noted in 1984 in a seminal article by Bruce Trigger. Trigger was convinced that "the nature of archaeological research is shaped to a significant degree by the roles that

2 The words of Max Weber at a gathering of sociologists in Vienna in 1908 quoted by PENNY 2003:250.

DOI: 10.1515/eas-2017-0010 C University of SS. Cyril and Methodius in Trnava. All rights reserved. 
particular nation states play, economically, politically, and culturally, as independent parts of the modern world system" (TRIGGER 1984:356; PATTERSON 1989). Consequently, he delineated three principal types of politicized archaeology: nationalist, imperialist and colonialist. The shared objective of national archaeologies worldwide was, in his interpretation, that of cementing national unity through the glorification of a supposed common past; colonialist archaeology sought, by emphasizing the primitiveness and lack of accomplishments of these non-European peoples, to justify economic and political dominance over them; while imperialist archaeology, associated with a small number of states that have exerted political dominance over large areas of the world, was characterized by an effort to gain the disproportionate influence throughout the world in the field of science as well.

This typology was subsequently developed by historians of science as well as practitioners of archaeology and also of anthropology - among others, by George Stocking, who in a series of volumes explored the complicated imperialist and colonialist background of nonEuropean anthropology (STOCKING 1991 and others). It certainly has its validity even for Central Europe ${ }^{3}$ and, specifically, for the Czech Lands. In the situation of a mosaic of small nations opposing themselves to each other as well as to the political superstructure of the Habsburg state, the study of local pre-history and local customs, that is, nationalist archaeology and anthropology/ethnology in Trigger's typology, was the most frequently pursued, and received greatest response from the public (e.g. TOMÁŠKOVÁ 2003). But surprisingly high number of proto-anthropologists and archaeologists - none of them actually studied in the field or dedicated to such activities professionally - were also interested in the non-European regions. Of course, the Czechs could not in the least dream of pursuing colonial enterprises and in fact they sometimes likened the fate of the nations of America and Africa to the unhappy history of the Slavs perishing under German expansion. ${ }^{4}$ Even less they could hope to imprint their own worldviews upon the rest of the scientific community in the imperialist fashion. But there was certain ideological motivation behind their endeavors, one that does not appear in Trigger's text and which I

3 While there is no consensus among historians about how to demarcate "Central Europe", it is used in the present text, with certain amount of simplification, as a synonym for that part of Europe that at the beginning of the $20^{\text {th }}$ century found itself either within the borders of the recently unified German Empire or under the dominance of the Habsburg dynasty ("AustroHungary"). For a discussion on the concept of Central Europe see HROCH 2016:58-68.

$4 \quad$ Such was the opinion voiced by the Czech writer Josef Václav Sládek when summarizing his experiences from North America (see SLÁDEK 1998:55-70).

DOI: 10.1515/eas-2017-0010 @ University of SS. Cyril and Methodius in Trnava. All rights reserved. 
denominate "aspirational". In their effort to prove that they could qualify as a fully-fledged and civilized nation, and especially compete with the Germans in all fields of intellectual and cultural activity, the Czechs pursued research in various fields and established a scientific terminology. The argument that some scientific activity should be realized because of what happened in the museums and at universities abroad or that the researcher amassed "collections richer than those in Berlin"s appeared relatively frequently.

But, interestingly enough, similar ambitions were manifested by German scientists in the Czech Lands, members of a strong ethnic minority that from the 1880s had begun losing the upper hand in politics and economy, a fact resented and widely commented on by its representatives. ${ }^{6}$ Throughout the nineteenth and at the beginning of the twentieth century, the Germans of Austro-Hungary also struggled to prove their high intellectual status and in this case, not their parity with the body of German culture and civilization, but rather the fact that they pertained to it. In other cases, they professed allegiance to the superstructure of the Habsburg state and "Austrian science", again accommodating their efforts to these external needs. While early Czech contributions to the history of anthropology or archaeology are studied nowadays, inter alia, as part of the national story, the activities of Czech Germans in the same field are being left aside. Therefore, the case of Julius Nestler (1877-1936?), who for most of his life oscillated between German (i.e. Imperial German) and Austrian allegiance, but whose collections ended up in the Náprstek Museum, that is, a museum established and maintained with explicit Czech patriotic ethos, is of extreme interest.

\section{High-school teacher with numerous interests}

Nestler came from a family of wide intellectual interests and markedly German national allegiance. He studied Classical Philology and German language and literature at the German university of Prague, passed the state exam in 1899 and two years later qualified as a high-school (Gymnasium) teacher. He pursued literary and historical studies early,

$5 \quad$ This was how the Czech traveler and amateur anthropologist Vojtěch (Alberto) Frič justified his voyages of exploration and his efforts to build in Prague a museum dedicated to South American Indians (see document annex in FRIČ 1977:242-243; for the specific motivations of Frič in his anthropological research, especially his clashes with the nationalistic ambitions of German anthropologists, see PENNY 2003).

6 For the complicated history of Czech Germans, see HOUŽVIČKA 2016, COHEN 2006.

DOI: 10.1515/eas-2017-0010 C University of SS. Cyril and Methodius in Trnava. All rights reserved. 
focusing on the study of mystics, first in Classical times, then in the modern period. While mysticism and occultism were at this time popular all over Europe, in Germany and AustroHungary they acquired special relevance, because they made it possible, through the development of "Aryan" racial and cultural theories, to justify the idea of German world rule (GOODRICK-CLARKE 2006) In his texts on occultist and theosophical themes Nestler also ostentatiously praised the German spirit and Aryan race. As was characteristic for his life-long career, in this early phase he had already acquired important patrons. He participated in the founding of the Austrian Astrological Society, whose members were prominent Austrian advocates, industrialists and artists. For this audience, he delivered a lecture on the topic of "Lost Atlantis" in 1906.

Maybe it was through Atlantis that Nestler became interested in American archaeology, even though none of his texts before 1908 explicitly mentioned the New World and he never explained in any of his texts why he decided to devote himself to the study of this region. ${ }^{7}$ After becoming a member of the Viennese Geographical Society in 1907, the next year he joined the French Société des Américanistes, a prominent association of scientists interested in archaeology, history and anthropology. Although he never mentioned his membership of occultist associations when communicating with protagonists of "standard" science, this was not true vice versa. On the contrary, Nestler habitually drew authority within the occultist milieu from his membership of the elite scientific organizations. Moreover, in both areas he used regularly the title "professor", without specifying that this was how high-school teachers were denominated in the Austro-Hungarian educational system. It seems that in the increasingly professionalized world of social sciences, Nestler who, in spite of his Classical education, lacked the necessary preparation as well as institutional embedding to pose as true scholar - tried to assert himself at least via nomenclature and references to authorities.

In September 1908 Nestler took part in the $16^{\text {th }}$ World Congress of Americanists in Vienna. His presentation was anything but original. It merely summarized information on the South American archaeological locality Tiahuanaco ${ }^{8}$ published in previous years by the English

7 He only sketched the possible association between Atlantis and America in one of his later texts, NESTLER 1911.

$8 \quad$ Even though the present-day official spelling of the name of the site is Tiwanaku, and the name "Tiahuanaco" is being used for the neighboring village after which the site was named, as the name by which the ancient city was known to its inhabitants is unknown today, I decided for the present text to keep to the older version, the one which appears in the sources used in the analysis.

DOI: 10.1515/eas-2017-0010 C University of SS. Cyril and Methodius in Trnava. All rights reserved. 
traveler Clements Markham and, especially, by the prominent German archaeologist active in South America, Max Uhle. Uhle himself - present at the assembly hall - openly commented on this lack of originality in the discussion. ${ }^{9}$ But this apparently did not trouble Nestler. In fact, even before the sessions of the Congress started he contacted the board with the proposition to "set up a committee to study the ruins of Tiahuanaco", again referring to Uhle concerning the significance of the site. He apparently asked for financial aid to accomplish his goal, but this was rejected and Nestler was instead recommended by the members of the board to "start an expedition on his own account". ${ }^{10}$ During his presentation two days later, Nestler really did announce his decision to follow up with this recommendation and himself pursue research into Tiahuanaco, "as a faithful pupil of director Uhle", founding "an Austrian station for Americanist research" on the shores of Lake Titicaca (NESTLER 1910:403). In other words, Nestler explicitly evoked the above mentioned aspirational discourse in non-European archaeology in Central Europe, promising to bring German-Austrian science to the level of the "advanced" nations of the West.

It was probably thanks to such a presentation of his project that he was able to attract various "big men" from economic and political circles to support him financially. Enumeration of Nestler's patrons and sponsors opened his most important article on Tiahuanaco from 1913. Among them figured Gustav Schreiner, a politician representing the interests of Germans in Bohemia and great opponent of the Czech patriots; Count Johann von Liechtenstein, again a politician with markedly "Austrian" allegiance; and Johann Huemer, a high official in the Ministry of Education of Austro-Hungary. Nestler alluded additionally to some prominent intellectuals: Leo Reinisch, Egyptologist and Africanist of Vienna University; David Heinrich Müller, Orientalist and Hebraist; Swiss philologist Wilhelm Meyer-Lübke; as well as Baron von Rothschild and the industrial magnate Eduard

$9 \quad$ XVI Intenationaler Amerikanisten-Kongreß, Wien/Leipzig 1910, p. Ix. Max Uhle had from 1896 conducted fieldwork in the Andes, first under the auspices of the Royal Ethnographic Museum of Berlin, then the University of Pennsylvania and the University of California and finally, as director of the National Archaeological and Historical Museum in Lima, of which he became the first director in 1906, effectively laying the framework for the archaeology of the Andean region (for his life story and bibliography, as well as a later evaluation of his work, see KAULICKE 1998; ROWE 1954).

10 XVI Intenationaler Amerikanisten-Kongre $\beta$, Wien/Leipzig 1910, p. xxv.

DOI: 10.1515/eas-2017-0010 @ University of SS. Cyril and Methodius in Trnava. All rights reserved. 
Jakob Weinmann from northern Bohemia, renowned for his philanthropic activities ${ }^{11}$ (NESTLER 1913:226-227). The support from Jewish scholars and entrepreneurs is especially interesting, in the view of the efforts in the 1860s and 1870s of the Jewish population in Austro-Hungary to participate fully in public life. Middle- and upper-class Jews at this period mostly entered German associations and defended the German national cause (COHEN 2006:58); hence, their common interest with Nestler.

Nestler also applied to various institutions for financial support. His letter of 1908, preserved in the archive of the Hamburg Ethnological Museum (Museum für Völkerkunde), promised to deliver artifacts to the museum in exchange for financial assistance for the journey to Bolivia. In this case at least, the request was denied and it is not known if he applied to other European museums. ${ }^{12}$ Nestler also asked the Austrian Ministry of Culture and Education for a stipend; again the results could not be ascertained. But there was probably some stipend from the "Society of German Researchers" (Bund Deutscher Forscher), to whom Nestler gave a promise to defend German - that is, not Austrian interests in America. At this moment, Germany pursued an active colonial policy in Africa, Asia and the Pacific and sought commercial penetration into Latin America. Even though it is not altogether clear how far German anthropologists and archaeologists actively contributed in formulating the colonial discourse, ${ }^{13}$ the nationalistic and imperialistic promulgations certainly found a response with the general public. Thus, Nestler's calls for aid in his endeavors could have resulted in some form of support.

There was at least one unsuccessful petition to the Society for Support of German Science, Art and Literature in Bohemia (Gesellschaft zur Forderung deutscher Wissenschaft, Kunst und Litteratur in Böhmen), again a nationalistic organization explicitly aiming at

11 Weinmann's son Edmund attended the Gymnasium in Litoměřice at the same time as Julius Nestler, so probably this acquaintance brought about not only financial aid, but also the first link in the chain of influential contacts.

12 This letter of April 10, 1908. with a copy of the negative reply of the museum curator, dated April 28, 1908, is preserved in the archive of the Hamburg Ethnological Museum; a copy was sent by an employee of this museum, Wolfgang Haberland, at the request of the curator of the Náprstek Museum, Josef Kandert, in 1989, and it is deposited in the documentation to the Nestler Collection. (Živá registratura NpM [Living Registry of the Náprstek Museum, hereafter NpM], fund Spisy dárců NpM, sl. Nestler, ff. 26-28, together with the correspondence between Kandert and Haberland, f. 45).

13 Glenn Penny in his inspiring and thorough monograph argued against the simplified portrayal of German anthropologists as "colonialists" and "imperialists". Even this author, however, admitted the turn from the cosmopolitan academic tradition to that tinted by nationalism and imperialism after the year 1900 (PENNY 2002).

DOI: 10.1515/eas-2017-0010 @ University of SS. Cyril and Methodius in Trnava. All rights reserved. 
strengthening of Germans against the Czechs. Nestler never asked the Náprstek Museum for a subsidy, or at least there is no documentation about such request in the museum archive. But he applied to the Czech Academy for Sciences, Literature and Arts (Česká akademie pro vědy, literature a umění), a markedly nationalistic Czech institution. Here, he simply accentuated the necessity to explore "the world famous ruins" of Tiahuanaco, without hinting at the nationalist question. ${ }^{14}$ And, last but not least, he acquired substantial financial support from occultists, from Germany and Austro-Hungary alike - within the frame, however, of strongly nationalist Aryan/German pronouncements, again playing the tune of the promises to elevate German science to highest levels. ${ }^{15}$

All this was proof of a capacity to maneuver within the various intellectual discourses of the times and making use of them. In a letter to Max Uhle from 1908 Nestler boasted that he was able to amass a considerable sum for his expedition, 20,000 German Marks. ${ }^{16}$ It is not certain how much of his own means he invested. Several articles published between 1910 and 1913 in periodical press and popular journals, in which he personally or via mediators asked for additional financial aid, accentuated the fact that his Bolivian expedition consumed "all his savings" (e.g. MANDEL 1910:27). In 1920, in rather bizarre context - the hearings of a trial for assisting three murders by poison in North Bohemia, in which Nestler was in the end acquitted - it was reported that he spent his wife's dowry on his scientific endeavors, thus causing a breakdown of his marriage. ${ }^{17}$ In any case, he

As for the corpus of the petitions, the one to the Society for Support of German Science and the one to the Czech Academy are almost identical. Both documents ended up in the same archive, namely, the Archive of the Czech Academy of Sciences (AAV, fund ČAVU, box 69, no. 116; AAV, fund Gesellschaft zur Förderung deutscher Wissenschaft, Kunst und Literatur in Böhmen, box 35, file Nestler J).

15 Nestler's departure for Bolivia, in explicit connection with the search for Atlantis, was mentioned in the German Zentralblatt für Okkultismus in an article published under initials, which asked "all friends of German scientific work" to support Nestler's endeavor; it confirmed that the Dresden branch of German Theosophical Society had already contributed to the project. ([O.Ms.] 1911/12: 611).

16 Letter from Julius Nestler to Max Uhle, Prague, 22-VI-1908, preserved in the holdings of the Ibero-Amerikanisches Institut, Berlin (hereafter IAI), as part of the great fund of Uhle's inheritance (fund Nachlass Uhle, no. N-0035, b252).

17 The documents from the trial, which took place in the city of Litoměrice in northern Bohemia and were deposited in the archive in the same city, were destroyed in a flood in 2002. However, the trial was covered by the local press. I am thankful to Mgr. Lada Kosmálová from State District Archives Teplice for rendering me copies of these documents. The mention of marital discord caused by Nestler through the spending of his wife's money in Bolivia appeared in the TeplitzSchönauer Anzeiger, no. 58, 11-III-1920, p. 4.

DOI: 10.1515/eas-2017-0010 C University of SS. Cyril and Methodius in Trnava. All rights reserved. 
probably hoped from the beginning to get his money back by selling the archaeological and anthropological artifacts acquired overseas. This did not necessarily mean sales into private hands; in fact, sales to museums or other cultural or educational institutions brought about similar gains and besides would render the vendor the status of a scientist acting in the public interest.

And there was another possible attraction for Nestler, embodied in the very choice of his field of activity. The picturesque ruins of Tiahuanaco near the shore of Lake Titicaca had been well known to Europeans, thanks to colonial chronicles and later reports of travelers and amateur archaeologists. ${ }^{18}$ Various speculations concerning the origins of American Indian cultures and humanity in general were attached to it, besides the intellectual competition between the Peruvian and the Bolivian archaeologists as for the importance of the site to the scheme of historical development of their respective nation states. But, more importantly, at the beginning of the twentieth century Bolivia became the target of intense economic penetration from part of European states, especially in the field of railroad construction, mining and the extraction of rubber, a material whose price on the international market rapidly increased due to the development of automobile industry. The German and Austrian armaments industry also aimed in the same direction (BIEBER 1984); and there were people connected with this field of activity named among Nestler's sponsors and patrons. ${ }^{19}$

An article in the German magazine Der Forscher, which in 1910 commented on Nestler's endeavors in Bolivia, alluded to "the common knowledge" that the United States and Great Britain gained an important footing by aiding their archaeologists; and that, "when one day the German capitalists come ahead of the [North Americans] in Bolivia, [...] they can build upon the already existing friendly relations [with local government] established by Professor Nestler". Allegedly quoting from Nestler's letter, the article evaluated the economic potential of the region, the possible benefits from the construction of a railroad, establishing the transcontinental connection of Atlantic and Pacific oceans through the Amazonas river, exploitation of "mines rich in ore", rubber forests and fields of sugarcane,

18 For the site and the history of its explorations, see PONCE SANGINÉS 1977 and PONCE SANGINÉS 1995; for the importance of the ruins for the nationalist discourse of Bolivia, SCABOROUGH 2008. The monumental two-volume work by Uhle on Tiahuanaco sparked enormous interest in Germany at the end of the 19th century (UHLE, STÜBEL 1893).

19 Among those was Baron Johann von Styrcea, Austro-Hungarian envoy in Santiago de Chile in the years 1906-12, involved actively in an effort to sell Austrian arms in Latin America (STOCKER - GRANT 2003:67).

DOI: 10.1515/eas-2017-0010 C University of SS. Cyril and Methodius in Trnava. All rights reserved. 
cacao and tobacco, and using the cheap workforce of local Indians. On subsequent pages the costs for the enterprise were calculated and great potential gains enumerated. The article concluded with the repeated instigation to all "true Germans" to follow up, adding "another link to the growing chain" of German enterprises all over the world. "For this goal: Germans, go on!" (MANDEL 1910:25-26).

Is seems from the above mentioned article that Nestler considered his "archeological" activities to be a mere cover or, at best, starting point for more profitable activities. The fact that he decided, alongside the archaeological excavations, to pursue linguistic research, choosing a Leco tribe, can serve as supporting argument for such a reading of his project. The Lecos, a small and, in the context of South American ethnology, little studied group at that time inhabited the course of river Mapiri-Keko in the eastern part of Bolivia - in other words, the rubber-extracting region, intensely exploited by North American companies. It is very probable that Nestler was interested in assessing the possibilities for such business, while for the study of Leco language, if there was any (although he repeatedly mentioned his linguistic endeavors, there is no article or report dedicated to them, nor did he explain why exactly he chose precisely this ethnic group), he merely used the book written by one of the colonial missionaries, published at the beginning of the nineteenth century in Rome (HERRERA 1834; for the "research" in eastern Bolivia NESTLER 1911:160). On the other hand, there is no proof that he actually accomplished any material result in the form of facilitating entrepreneurial penetration by some German company in the region, or that he acquired any financial profit.

\section{Research in Tiahuanaco}

As for his archaeological excavations, as early as 1906 the National Congress of Bolivia passed a law prohibiting the export of objects from Tiahuanaco as well as from other sites and subjecting any surveys in the place to the oversight of the state (YATES 2011:293). Such prohibitions, however, did not hinder Nestler, who carried out extensive diggings whose traces remain until the present day. According to the prominent Bolivian scholar Carlos Ponce Sanginés, Nestler had done this in the most primitive way, with the sole objective of removing buried objects, and apparently with no effort to map the stratigraphic context. ${ }^{20} \mathrm{He}$ never showed any interest in the native inhabitants of the Tiahuanaco basin, Museum there are no field notes of any kind.

DOI: 10.1515/eas-2017-0010 C University of SS. Cyril and Methodius in Trnava. All rights reserved. 
with the exception of the above mentioned "linguistic" sojourn in the Bolivian lowlands. From his texts it is clear that he shared the conviction of many of his contemporaries that the builders of Tiahuanaco and many other famous archaeological sites were members of some noble race preceding the Indian population. This population therefore was not the in the least interesting to him, with the exception of buying artifacts from the Aymara villagers in the vicinity, both archaeological and ethnographical.

There is in fact a strong possibility that not all the artifacts in the collection deposited in the Náprstek Museum are authentic. In 1910 a Congress of Americanists took place in Buenos Aires. A group of participants, among whom there were also some Austrian scholars, toured Tiahuanaco and Nestler apparently served as their guide. One of the participants of the excursion, the Argentinian anthropologist Salvadore Debenedetti, remarked sarcastically, albeit without giving any names: "Unemployed boys were selling to travelers painted shards, collected from the immense pile of broken vases and jars that covers the place. [...] One little rascal was offering for sale a piece of broken candlestick from the church, $[\ldots]$ and another from a telegraph pole. [...] One excursionist amassed this material carefully and in a short while greatly increased his collections of archaeological material from Tiahuanaco" (DEBENEDETTI 1912:645). It should be mentioned that extensive forging of archaeological material was a deep-rooted tradition in the Andean region. The German traveler Johann-Jakob Tschudi remarked as early as in 1884 that "not one in ten" Andean pottery vessels deposited in German collections was authentic; they were rather a product of one of the numerous workshops prospering all over the region (TSCHUDI 1884:42). Because of the use of local materials, it would be extremely difficult nowadays to really sort out the forgeries from the originals in these collections. But at least the supplementary information could warn scholars to exercise greater caution when processing the museum collections.

How Nestler was able to export his assemblage of artifacts - which included stone fragments of considerable bulk and weight - from Bolivia, in spite of the laws prohibiting such export of cultural material, remains undocumented; but undoubtedly he used his political connections and letters of recommendation. He returned to Prague sometime in 1912, assuming his teaching duties in September of this year. But as early as January 1913 he was on another long-term leave, with the purpose of "working on the collections acquired during the study stay in South America". He returned to teaching only in 1916/17, and from the next year again assumed unpaid leave. It is possible that this was for reasons 
of health - apparently, Nestler contracted malaria during his stay in low-lying parts of Bolivia. ${ }^{21}$ In any case, he did not even try to make use of his travel experiences in his teaching career, as some of "traveling professors" at the turn of the century did, mostly again within the frame of the nationalistic evocations of the need to elevate the youth to higher levels of education and culture. ${ }^{22}$

Instead, Nestler tried to capitalize upon his travels in a different way. He gave public lectures for paying audiences, again mostly to nationalist German clubs and associations in Prague and other bigger cities of Bohemia. He unsuccessfully requested a financial subsidy from the Society for Support of German Science, Art and Literature in Bohemia to publish a book about Tiahuanaco, ${ }^{23}$ but at least summarized the results of his stay in Bolivia in an article published in the journal of the Viennese Geographical Society. This is his bestknown and cited text, even though again it mostly repeats opinions on Tiahuanaco given by other authors (NESTLER 1913). It seems that mainly it served Nestler as self-promotion in his effort to sell his collections. In 1913 he sent another letter to the Ethnological Museum in Hamburg, offering all of the artifacts for the considerable sum of 150,000 German Marks, or the most valuable ones, such as stone sculptures or gold pieces, separately. In this letter he again invoked nationalistic discourse, suggesting that, if the museum itself did not dispose of such sums, the "rich Senators and Burghers of Hamburg" could render support, for the greater good of assisting the further intellectual growth of the German nation. Nevertheless, the offer was rejected by the directorship of the Museum. ${ }^{24}$

At the same time (in December 1913), Nestler offered his collection to the Museum of Ethnology in Vienna. In this case, the Museum agreed to buy some artifacts, and an amount of 300 crowns was transferred to Nestler. Surprisingly, the money was sent to London, even though there were no previous contacts of Nestler with England, and via the secretariat of Baron Rothschild (also named among the sponsors of Nestler in his article for the journal of the Geographical Society). But it seems the artifacts were never delivered to the museum in

21 This was stated during the previously mentioned trial in 1920; see Teplitz-Schönauer Anzeiger, no. 58, 11-III-1920, p. 4.

22 The case of the Czech high-school professor Josef Kořenský was typical, see TODOROVOVÁ 1996, but there were in the Czech Lands also German teachers with similar aspirations.

23 AAV, fund Gesellschaft zur Förderung deutscher Wissenschaft, Kunst und Literatur in Böhmen box 35, file Nestler J.

24 Letter from Nestler to the Museum für Völkerkunde, Hamburg, 22-VII-1912, and response dated 4-VII-1913, copies in NpM, fund Spisy dárců NpM, sl. Nestler, ff. 34-37.

DOI: 10.1515/eas-2017-0010 @ University of SS. Cyril and Methodius in Trnava. All rights reserved. 
Vienna and there is no reference to Nestler in its inventories. ${ }^{25} \mathrm{We}$ do not know if Nestler tried with some other institutions or private collectors, nor how many objects he was able to sell. For example, the letter to the Museum in Hamburg mentions five stone heads, probably from the walls of the "Sunken Courtyard" in Tiahuanaco, but only two of them are preserved in the Náprstek Museum; and in the inventories of the same museum there is not a single one of the gold pieces that were again mentioned in a letter to Hamburg. ${ }^{26} \mathrm{~A}$ detailed reconnaissance in various European museums would be needed. But it seems the bulk of the collection remained in Nestler's hands throughout World War I.

\section{The Nestler Collection}

After 1918 Nestler resumed his efforts to sell the artifacts, resigning, however, efforts to attract foreign institutions. Instead, he aimed at the government of the newly founded Czechoslovak Republic. In December 1920 he exhibited the collection - at his own cost in the Museum of Decorative Arts in Prague. The event had considerable promotion, being inaugurated by a lecture by Vojtěch Suk, a prominent Czech physician and anthropologist known for his travels in Africa at the turn of the century. In other words, there was an effort to address the Czech public, in whom Nestler in the previous period took no interest at all. (All his public lectures in the pre-war period were in German; judging from his official correspondence preserved in the Náprstek Museum, his command of the Czech language was mediocre.)

The promotion of the exhibition was led in a way that leaves no doubt as to its "aspirational" ambition for the new Czechoslovak nation to get on a par with the developed nations of Europe even in the exotic field of Americanist studies. The report of the curators of the Museum for the year 1920 stated that it was "not only the first exhibition of this kind on the territory of Czechoslovakia, but [...] in Europe." ${ }^{27}$ Similarly, the newspaper Národni listy noted that for the first time Czechoslovaks interested in American art did not need to

25 I would like to thank Dr. Claudia Augustat, the curator of the South American Collection of the Museum of Ethnology in Vienna, for rendering me the information and copies of documents from the archive of the museum.

26 I would like to thank Mgr. Ludmila Škrabáková, the curator of the South American Collection the Náprstek Museum, for allowing me the study of the collection and rendering me all the necessary information.

27 Excerpts of the reports in NpM, fund Spisy dárců NpM, sl. Nestler, s.f.

DOI: 10.1515/eas-2017-0010 @ University of SS. Cyril and Methodius in Trnava. All rights reserved. 
"resort to foreign museums". ${ }^{28}$ And Karel Herain, specialist in applied art and future director of the Museum of Decorative Arts, stated very clearly in his review of the event: "It would be of great scientific and cultural profit if this collection could be salvaged for the republic through purchase by the state" (HERAIN 1921). In fact, the evaluations were not exaggerated, even when we take into account the possibility of counterfeits - not known at the time - and the fact that fragments of pottery vessels constituted the bulk of the collection (more than half of it). Given the poor accessibility of Tiahuanaco and the early attempts of the Bolivian government to prevent the export of archaeological artifacts, there was and is hardly a similar collection in European museums.

Nestler achieved his goal. As early as in July of the next year, the Ministry of Education and National Culture bought the whole collection, altogether more than 3,000 archaeological artifacts (stone, metal and ceramic) and 500 ethnographic ones (such as textiles and household utensils), supplemented with Nestler's books on the old civilizations and ethnography of South America, for the considerable sum of 100,000 Czechoslovak crowns. This, however, was not given in full, but was supposed to be paid in yearly installments of 4040 crowns until Nestler's death, which means that the state effectively paid about half of the amount. The artifacts were taken over by the State Archaeological Institute, examined cursorily and then deposited in the Náprstek Museum, which however lacked the personnel for their proper treatment (LOUKOTKA 1958).

We have no precise information concerning Nestler's last years (he died in January $1936^{29}$ ). But as far as can be judged from the fragmentary evidence, after successfully selling his collection he abandoned archaeology and considered his voyage to Tiahuanaco and his venture into Americanist studies to be closed episodes. Instead, he dedicated himself fully to occultism, which experienced great expansion in Central Europe in the interwar period. What is interesting is that in this field too he associated extensively with Czechs and abandoned completely the ostentatious German posture he assumed in the pre-war period. Of course, the political situation in Czechoslovakia in the 1920s was not favorable to manifestations of German nationalism; however, in the 1930s the "great German" discourse was again in the rise, making possible for the adherents of German nationalism to enter political or cultural arena. (HOUŽVIČKA 2016) That Nestler did not do such thing and

29 According to the Salzburger Volksblatt, 31-I-1936, p. 7, the death of "Julius Nestler of Prague Professor in retirement" was reported to occur on January 29. (I am indebted to Alexandra Nagel from Leiden University, who noticed the announcement in the newspaper.)

DOI: 10.1515/eas-2017-0010 @ University of SS. Cyril and Methodius in Trnava. All rights reserved. 
instead kept to the circles of Czech occultists seems to indicate that his pronouncements from the pre-1918 period were a pose aimed at attracting sponsors and patrons rather than an expression of deeply-felt national allegiance.

In 1962, apparently in reaction to an impulse from the Bolivian side, the then Czechoslovak Ministry of Education and Culture made inquiries about the contents and importance of the "Nestler Collection". ${ }^{30}$ At the beginning of the 1980s as well, voices could be heard in Bolivia loudly condemning the continuation of the massive illegal export of tangible cultural heritage from the country; Nestler's name and the artifacts in the Náprstek Museum were mentioned, even though most of the criticism was directed towards North American institutions (SAGÁRNAGA MENES 1985). The Bolivian government never made any effort to reclaim the collection, which remains one of the highlights of the South American exhibit of the Museum. ${ }^{31}$ But the leading specialist in Tiahuanaco, Carlos Ponce Sanginés, has repeatedly accused Nestler of committing "cultural piracy" (PONCE SANGINÉS 1995:123-124).

Even when taking into account the persistent efforts of Bolivian archaeologists to protect the cultural heritage of their country against encroachment from abroad and the strongly nationalistic representation of pre-Columbian cultures, we cannot disagree with these strong words. The unique collection housed nowadays in the Náprstek Museum was amassed by a man whose principal goals were material gain and fame. Nestler never tried to break through the paradigms of his time, to bring forward new interpretations, but merely followed and copied the dominant discourse, always backing himself up with the opinions of the most prominent members of the circles in which he tried to assert himself. He openly mixed scientific research with entrepreneurial activity and the archaeological and ethnographical artifacts were for him nothing more than merchandise to be turned into money. While sailing on the "aspirational" wave of Americanist studies in Central Europe, in reality these aspirations were eminently personal. It remains to be inferred from the further study of similar cases if such motivations were more commonplace among (not only) the Americanist anthropologists and archaeologists of his era than might seem from present-day works on the history of the disciplines, as neither Trigger nor those who commented upon and elaborated his typology took them into account.

Živá registratura NpM [Living Registry of the Náprstek Museum, hereafter NpM], fund Spisy dárců $\mathrm{NpM}$, sl. Nestler, II.1.2., f. 7, response of the museum curator ff. 8-9.

31 At present, however, the whole American exhibit is closed to the public due to repairs and remodeling.

DOI: 10.1515/eas-2017-0010 @ University of SS. Cyril and Methodius in Trnava. All rights reserved. 


\section{Bibliography}

BIEBER, León Enrique: Las relaciones económicas de Bolivia con Alemania, 18801920. Berlin: Colloquium Verlag 1984.

COHEN, Gary B.: The Politics of Survival: Germans in Prague, 1861-1914. West Lafayette, Ind.: Purdue University Press, 2006 ( $\left.2^{\text {nd }} e d\right)$.

COOPER, Frederick - STOLER, Laura: Tensions of Empire: Colonial Cultures in a Bourgeois World. Berkeley: University of California Press, 1997.

DEBENEDETTI, Salvador: "Excursión del XVII' Congreso Internacional de Americanistas á Bolivia y Perú (Del diario de viaje)". Actas del XVII Congreso Internacional de Americanistas (Buenos Aires 1910), Buenos Aires: Impr. de Coni hermanos, 1912, pp. 641-645.

FRIČ, Alberto Vojtěch: Indiáni Jižní Ameriky [Indians of South America], Praha: Orbis 1977.

GOODRICK-CLARKE, Nicholas: The Occult Roots of Nazism: Secret Aryan Cults and their Influence on Nazi Ideology. New York: New York University Press, 2004 (2 ${ }^{\text {nd }}$ ed).

HERAIN, Karel: "Výstava staroperuánského umění” [Exhibition of Old Peruvian Art]. Drobné umění 2:1 (1921), p. 16.

HERRERO, Antonio: Doctrina y Oraciones Cristianas en lengua Mosetena tradicidos en español, palabra por palabra. Roma: Imprenta de Propaganda, 1834.

HOUŽVIČKA, Václav: Czechs and Germans 1848-2004: The Sudeten Question and the Transformaton of Central Europe. Praha: Karolinum, 2016.

HROCH, Miroslav: Hledání souvislostí: Eseje z komparativních dějiny Evropy [Looking for connections: Essays from comparative history], Praha: Sociologické nakladatelství, 2016.

KAULICKE, Peter (ed.): Max Uhle y el Perú Antiguo. Lima: Fondo Editorial, 1998.

KŘížOVÁ, Markéta: Julius Nestler and the 'Nestler Collection' in the Náprstek Museum: Nationalism, Occultism and Entrepreneurship in the making of Americanist archaeology in Central Europe". Annals of the Náprstek Museum 37/2 (2016), pp. 1732.

LOUKOTKA, Čestmír: Une collection inconnue de Tiahuanaco. Proceedings of the 32nd International Congress of Americanists (Copenhagen 1956), Copenhagen: Munksgaard, 1958, pp. 333-345.

MANDEL, Karl: Die Atlantis - ein neues Kolumbusei. Der Forscher: Illustriertes Zentralblatt für Deutsche Forschung, 1910:1, pp. 1-5, 1910:2, pp. 23-27.

DOI: 10.1515/eas-2017-0010 @ University of SS. Cyril and Methodius in Trnava. All rights reserved. 
NESTLER, Julius: Die Bedeutung der Ruinenstätte von Tiahuanaco nach den Publikationen von Dr. Max Uhle und Sir Clements Markham. XVI Internationaler Amerikanisten-Kongre $\beta$. Wien/Leipzig: Hartleben's Verlag, 1910, pp. 395-403.

NESTLER, Julius: Atlantis-Forschung und Amerikanistik. Der Forscher: Illustriertes Zentralblatt für Deutsche Forschung, 1911, Heft 10/11, pp. 137-140, Heft 12, pp. 157160.

NESTLER, Julius: Beiträge zur Kenntnis der Ruinenstätte von Tiahuanaco. Mitteilungen der Kais. Königl. Geographischen Gesellschaft in Wien, 1913, 56(4), pp. 227-236; 56(5), pp. 268-297.

[O.Ms.]: Atlantis-Forschung. Zentralblatt für Okkultismus: Monatsschrift zur Erforschung der gesamten Geheimwissenschaften, 5 (10), (1911/12), p.611.

PATTERSON, Thomas C.: Political economy and a discourse called 'Peruvian archaeology'. Culture and History, 4:1 (1989), pp. 35-64.

PENNY, Glenn: Objects of Culture: Ethnology and Ethnographic Museums in Imperial Germany. Chapel Hill/London 2002.

PENNY, Glenn: The Politics of Anthropology in the Age of Empire: German Colonists, Brazilian Indians, and the Case of Alberto Vojtěch Frič. Comparative Studies in Society and History 45:2 (2003), pp. 249-280.

PONCE SANGINÉS, Carlos: Tiwanaku: 200 aňos de investigaciones arqueológicas. La Paz: Producciones CIMA, 1995.

SAGÁRNAGA MENESES, José Antonio: Miles de piezas arqueológicas bolivianas enriquecen museos de todo el mundo. Presencia, 17-2-1985, p. 4.

SCARBOROUGH, Isabel: The Bennett Monolith: Archaeological Patrimony and Cultural Restitution in Bolivia. In. The Handbook of South American Archaeology, ed. Helaine Silverman - William H. Isbell. New York: Springer-Verlag, 2008, pp. 10891101.

SLÁDEK, Josef Václav: Má Amerika: Fejetony a přihody, 1871-1892 [My America: Feuilletons and stories, 1871-1892], eds. Jaroslava Janáčková, Jarmila Víšková, Praha 1998.

STOCKER, Donald J. - GRANT, Jonathan A.: Girding for Battle: The Arms Trade in a Global Perspective, 1815-1940. Westport, CT: Praeger, 2003

STOCKLING, George (ed.): Colonial Situations: Essays on the Contextualization of Ethnographic Knowledge. Madison: University of Wisconsin Press, 1991. 
TODOROVOVÁ, Jiřina: Josef Kořenský - nejen cestovatel [Josef Kořenský - not only traveler], Český lid 83:1 (1996), pp. 48 - 51.

TOMÁŠKOVÁ, Silvia: Nationalism, Local Histories and the Making of Data in Archaeology. The Journal of the Royal Anthropological Institute 9:3 (2003), pp. 485507.

TRIGGER, Bruce G.: Alternative Archaeologies: Nationalist, Colonialist, Imperialist. Man 19:3 (1984), pp. 355-370.

TSCHUDI, Johann-Jakob: Organismus der Khetsua-Sprache. Leipzig: F.A. Brockhaus, 1884.

UHLE, Max, STÜBEL, Alphons: Die Ruinenstaette von Tiahuanaco im Hochlande des Alten Perú: Eine kulturgeschichtliche Studie auf Grund selbstaendiger Aufnahmen. Leipzig: Hiersemann, 1893.

YATES, Donna: Archaeology and autonomies: the legal framework of heritage management in a new Bolivia. International Journal of Cultural Property 18:3 (2011), pp. 291-307. 